\title{
PENGARUH PEMBELAJARAN KOOPERATIF TIPE TEAMS GAMES TOURNAMENT BERBANTUAN AUDIO VISUAL TERHADAP HASIL BELAJAR PESERT DIDIK KELAS XI IPA
}

\author{
St. Nurhalisah \\ Universitas Muslim Maros, $\underline{\text { Sittinurhalisah9@gmail.com }}$
}

\begin{abstract}
Abstrak
Jenis penelitian yang digunakan adalah quasi Eksperimental Designs. Penelitian ini merupakan penelitian eksperimen semu karena tidak semua variabel dapat dikontrol secara ketat. Penelitian ini menggunakan rancangan "One-Group Pretest-Posttest Design Dalam desain penelitian eksperimen ini ada satu kelompok yaitu kelas eksperimen saja. Populasi dalam penelitian ini adalah siswa kelas XI IPA SMA Negeri 20 Pangkep yang berjumlah 2 kelas yaitu kelas XI IPA 1 dan XI IPA 2 dimana siswa kelas XI IPA 1 berjumlah 32 dan XI IPA2 berjumlah 34 siswa, jadi populasi dalam penelitian ini berjumlah 66 siswa di SMA Negeri 20 Pangkep. Dalam penelitian ini terdapat dua variabel, yaitu: variabel bebas (X) danvariabel terikat (Y). Teknik pengumpulan data yang digunakan yaitu Tes yang berbentuk soal pilihan ganda sebanyak 20 soal.Tes digunakan untuk mengukur hasil belajar siswa pada kelas eksperimen yang menggunakan model kooperatif tipe Teams Games Tournamen. Instrumen pada penelitian ini adalah peneliti yang menggunakan instrumen berupa soal dan dokumentasi. Teknik analisis data yang digunakan adalah deskriptif statistik dan deskriptif inferensial. Hasil analisis derskriptif pada Pre-Test dengan standar deviasi 15,42 sedangkan hasil Pos-Test dengan standar deviasi 10,58. Hasil uji normalitas pada Pre-Test senilai 0,586 sedangkan pada Pos-Test senilai 0,186. Pada uji homogenitas, hasil Pre-Test dan Pos-Test sebanyak 0,087 serta berdasarkan hasil uji hipotesis, nilai t tabel sebesar 1,998341 dan t hitung sebesar 29,396 dimana t tabel $<\mathrm{t}$ hitung sehingga berdasarkan kriteria pengujian untuk uji hipotesis dinyatakan Ho ditolak sehingga $\mathrm{H} 1$ diterima yang berarti ada pengaruh penggunaan model pembelajaran kooperatif tipe Teams Games Tournament berbantuan audio visual terhadap hasil belajar peserta didik.
\end{abstract}

Kata kunci: Pengaruh, Teams Games Tournament, Hasil Belajar

\begin{abstract}
This research type was quasi experimental designs. This research wasaquasiexperimental Study because not all variables can be tightly controlled. This study used the designof"One-Group Pretest-Posttest Design. In this experimental research design there is one group, namely the experimental class only. The population in this study were students of class XI IPA of SMA Negeri 20 Pangkep totaling 2 classes, namely class XI IPA 1 and XI IPA 2 where students of class XI IPA1 were 32 and XI IPA 2 amounted to 34 students, so the population in this study amounted to 66 students in Pangkep 20 Public High School. In this study there were two variables, namely :the independent variable $(\mathrm{X})$ and the dependent variable(Y). Data collection techniques used were tests in the form of multiple choice questions of 20 questions. The test used to measure student learning outcomes in the experimental class using a cooperative model of theTeams Games Tournament. The instruments in this study were researchers
\end{abstract}


who used instruments in the form of questions and documentation. Data analysis techniques used are descriptive statistics and inferential descriptive. The results of the descriptive analysis were pretest with a standard deviation of 15.42 while the posttes tresults with a standard deviation of 10.58. The results of normality tests at pretest worth 0.586 while at posttest worth 0.186 . In the homogeneity test, the results of the pretest and posttest were 0.087 and based on the results of the hypothesis test, the value of $t$ table was 1.998341 and $t$ arithmetic was 29.396 where $t$ table $<t$ counted so that based on the test criteria for hypothesis testing stated Ho was rejected so that H1 was accepted which meant there was the influence of the use of theTeams GamesTournament cooperative learning model with audio visual aids on student learning outcomes.

Key word: Effect, Teams GamesTournament, learning outcomes

\section{PENDAHULUAN}

Menurut Yahya dalam (Pramita Arif, 2018, p. 12) Kemajuan kehidupan berbangsa dan bernegara dapat dilihat dari perkembangan pendidikan. Pendidikan tak lain sebagai lembaga dan usaha pembangunan bangsa dan watak bangsa. Pada hakekatnya pendidikan adalah pengaruh, bimbingan, arahan agar menjadi dewasa, mandiri dan memiliki kepribadian yang utuh dan matang.

Oleh karena itu, guru dituntut untuk menggunakan model yang bervariasi tidak hanya ceramah saja, tetapi juga model lainnya seperti model pembelajaran yang lebih menekankan pada pembelajaran aktif, kreatif, efektif dan menyenangkan. Pemilihan model pembelajaran sangat mempengaruhi keberhasilan peserta didik. Oleh karena itu, diperlukan model pembelajaran yang mampu mengaktifkan peserta didik dalam proses belajar mengajar agar lebih menyenangkan dan merasa lebih percaya diri akan kemampuan yang mereka miliki yang dilakukan dengan kerja kelompok. Model TGT (Team Games Tournament) ialah suatu tipe atau model pembelajaran yang mudah diterapkan, melibatkan aktivitas seluruh siswa tanpa harus ada perbedaan status, mengandung permainan dan penguatan (Rosdiani, 2014).

Menurut Arsyad dalam (Septiawan et al., 2017, p. 4) dengan media audio visual, siswa dapat meningkatkan pemahamannya karena media audio visual dapat menarik dan memotivasi siswa untuk mempelajari materi lebih banyak. Dengan demikian pembelajaran di kelas akan mudah di terima oleh siswa. Tidak hanya itu, media audio visual dapat menimbulkan 
ketertarikan atau perhatian yang menyebabkan timbulnya rasa senang pada diri siswa, yang pada akhirnya akan mendatangkan ketertarikan dan kepuasan pada diri siswa.

$$
\text { Model TGT jika }
$$

dikombinasikan dengan media audio visualakan menciptakan suasana belajar yang lebih aktif dan menyenangkan, karena dengan adanya media audio visual akan memicu rasa ingin tahu siswa terhadap materi yang diajarkan. Media audio visual disebut juga sebagai media video. Video merupakan media yang digunakan untuk menyampaikan pesan pembelajaran. Terdapat dua unsur yang saling bersatu dalam media video yaitu audio dan visual (Anggraini, 2017).

\section{METODE PENELITIAN}

Jenis penelitian yang digunakan adalah quasi Eksperimental Designs. Penelitian ini merupakan penelitian eksperimen semu karena tidak semua variabel dapat dikontrol secara ketat.

Penelitian ini dilakukan pada satu kelas. Kelas eksperimen diberikan perlakuan dengan menggunakan model pembelajaran kooperatif Teams Games

\section{Tournament.}

Desain Penelitian "One-Group Pretest-Posttest Design dalam desain penelitian eksperimen ini ada satu kelompok yaitu kelas eksperimen saja. Pada penelitian kelas eksperimen desain penelitian One-Group Pretest-Posttest Design yang memilih sampel secara random melainkan dengan tujuan tertentu yaitu melihat kesetaraan dari kelas eksperimen. Desain penelitian One-Group Pretest-Posttest Design di gambarkan sebagai berikut :

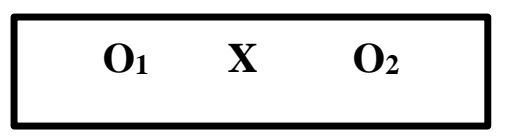

Keterangan :

$\mathrm{O}_{1}$ : Pre testkelas eksperimen

$\mathrm{O}_{2}$ : Post test kelas ekperimen

X : Perlakuan pada kelas

eksperimen dengan model

pembelajaran TGT

Berdasarkan desain penelitian yang telah dipaparkan, penelitian melakukan dua kali tes pada kelas. Setelah kelas melakukan tes akhir kemudian hasil dibandingkan atau diuji perbedaannya. Perbedaan yang signifikan antara kedua nilai di kelas eksperimen akan menunjukkan pengaruh dari perlakuan yang telah diberikan.

Penelitian ini dilaksanakan pada bulan April-Mei tahunajaran 2019/ 2020. Tempat penelitian adalah SMA Negeri 20 Pangkep. Populasi dalam penelitian ini adalah siswa kelas XI IPA SMA Negeri 20 Pangkep yang berjumlah 2 
kelas yaitu kelas XI IPA 1 dan XI IPA 2 dimana siswa kelas XI IPA 1 berjumlah 32 dan XI IPA2 berjumlah 34 siswa, jadi populasi dalam penelitian ini berjumlah 66 siswa di SMA Negeri 20 Pangkep.

Sampel yang diambil dalam penelitian ini sebanyak satu kelas. Satu kelasyang dijadikan sebagai kelas eksperimen. Adapun pengambilan sampel dilakukan dengan teknik Simple Random Sampling.

Teknik pengumpulan data di kumpulkan pada saat penelitian sudah selesai dilaksanakan penelitian dan datadatanya sudah sesuai apa yang sudah di capai dan di buktikan oleh peneliti. Teknik pengumpulan data yang digunakan yaitu :

1. Tes yang berbentuk soal pilihan ganda sebanyak 20 soal.

2. Tes digunakan untuk mengukur hasil belajar siswa pada kelas eksperimen yang menggunakan model kooperatif tipe Teams Games Tournament

Teknik Pengumpulan Data di kumpulkan pada saat penelitian sudah selesai dilaksanakan penelitian dan datadatanya sudah sesuai apa yang sudah di capai dan di buktikan oleh peneliti. Teknik pengumpulan data yang digunakan yaitu: Tes yang berbentuk soal pilihan ganda sebanyak 20 soal.

\section{HASIL DAN PEMBAHASAN}

Deskripsi hasil penelitian ini menggambarkan hasil belajar Peserta Didik sebelum dan sesudah diberikan perlakuan berupa model pembelajaran kooperatif tipe Teams Games Tournament Berbantuan Audio Visual Terhadap Hasil Belajar Biologi Peserta Didik Pada Materi Sistem Reproduksi Manusia pada kelas eksperimen

Tabel.2 Distribusi Nilai Statistik Hasil Belajar Biologi Pre-Test dan PostTest kelas XI IPA di SMA Negeri 20 Pangkep

\begin{tabular}{|c|c|c|}
\hline $\begin{array}{l}\text { Kategorinilai } \\
\text { statistic }\end{array}$ & Pre-test & Post-test \\
\hline Nilaitertinggi & 90 & 95 \\
\hline Nilaiterendah & 20 & 45 \\
\hline Mean & 53,4375 & 73,4375 \\
\hline Median & 50 & 75 \\
\hline Range & 75 & 50 \\
\hline Standardeviasi & 15,42084 & 10,58281 \\
\hline Varians & 237,8024 & 111,996 \\
\hline
\end{tabular}

Berdasarkan Tabel 2 menunjukkan bahwa nilai statistik hasil belajar biologi peserta didik dengan menggunakan Model Pembelajaran Kooperatif tipeTeams Games Tournament Berbantuan Audio Visual Terhadap Hasil Belajar Biologi Peserta Didik Kelas XI IPA Pada Materi Sistem Reproduksi Manusia mengalami perubahan yang positif. Bahwah diketahui nilai tertinggi pada Pre-Test 90 
dan Post-Test 95, nilai terendah dari PreTest 20 dan Post-Test 45, Nilai Mean dari Pre-Test 53,4375 dan Nilai Mean Post-Test 73,4375, Median dari Pre-Test 50 dan Post-Test 75, Range padaPre-Tes t75 dan Post-Test 50, Standar Deviasi Pre-Test 15,42084 dan Post-Test 10,58281, Varians pada Pre-Test 237,8024 dan Post-Test 111,996. Berikut Statistik hasil belajar biologi Pre-Test dan Post-Test dapat dilihat pada gambar 1 sebagai berikut:

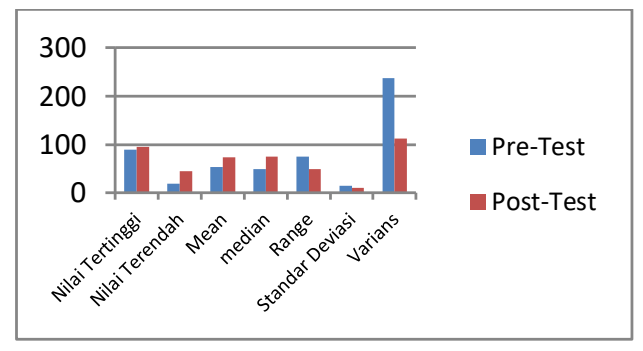

Gambar.1 Statistik Nilai Hasil Belajar Biologi Pre-Test dan Post-Test kelas XI IPA di SMA Negeri 20 Pangkep

b. Kategori Hasil Belajar

Tabel.3 Distribusi Kategori dan frekuensi Hasil Belajar Biologi Pre-Test kelas XI IPA di SMA Negeri 20 Pangkep

\begin{tabular}{|c|c|c|c|c|}
\hline $\begin{array}{l}\mathrm{N} \\
\mathrm{O}\end{array}$ & $\begin{array}{c}\text { Interval } \\
\text { nilai }\end{array}$ & Kategori & $\begin{array}{c}\text { Freku } \\
\text { ensi }\end{array}$ & $\begin{array}{l}\text { Persent } \\
\text { ase }(\%)\end{array}$ \\
\hline 1 & $85-100$ & $\begin{array}{c}\text { Sangatba } \\
\text { ik }\end{array}$ & 1 & $3,1 \%$ \\
\hline 2 & $71-84$ & Baik & 2 & $62 \%$ \\
\hline 3 & $66-70$ & Cukup & 3 & $9,3 \%$ \\
\hline 4 & $0-65$ & Kurang & 26 & $81,2 \%$ \\
\hline & Jumlah & & 32 & $100 \%$ \\
\hline
\end{tabular}

Sumber: Diolah dari data SPSS 25.
Berdasarkan Tabel 3 Kategori dan frekuensi hasil belajar Peserta Didik biologi Peserta Didik dengan menggunakan Model Pembelajaran Kooperatif tipe Teams Games Tournament Berbantuan Audio Visual Terhadap Hasil Belajar Biologi Peserta Didik Kelas XI IPA Pada Materi Sistem Reproduksi Manusia dapat dilihat pada Tabel Pre-Test diatas peserta didik yang mendapatkan interval nilai $85-100$ dengan kategori sangat baik sebanyak 1 peserta didik dengan persentase sebesar $3,1 \%$, peserta didik yang mendapatkan interval nilai 71-84 dengan kategori baik sebanyak 2 peserta didik dengan persentase sebesar 62\%, 66-70 dengan kategori cukup sebanyak 3 peserta didik dengan persentase sebesar 9,3\%, 0-65 dengan kategori kurang 26 pesrta didik dengan persentase sebesar $81,2 \%$.

Tabel.4 Distribusi Kategori dan frekuensi Hasil Belajar Biologi Post-Test kelas XI IPA di SMA Negeri 20 Pangkep

\begin{tabular}{lllll}
\hline $\begin{array}{l}\mathrm{N} \\
\mathrm{O}\end{array}$ & $\begin{array}{l}\text { Interval } \\
\text { nilai }\end{array}$ & Kategori & $\begin{array}{l}\text { Freku } \\
\text { ensi }\end{array}$ & $\begin{array}{l}\text { Persen } \\
\text { tase } \\
(\%)\end{array}$ \\
\hline 1 & $85-100$ & $\begin{array}{l}\text { Sangatba } \\
\text { ik }\end{array}$ & 8 & $25 \%$ \\
2 & $71-84$ & Baik & 9 & $281 \%$ \\
3 & $66-70$ & Cukup & 6 & $18,7 \%$ \\
4 & $0-65$ & Kurang & 9 & $28,1 \%$ \\
\hline
\end{tabular}




\begin{tabular}{ccc}
\hline Jumlah & 32 & $100 \%$ \\
\hline Sumber: Diolah dari data SPSS & 25
\end{tabular}

Berdasarkan Tabel 4 Kategori dan frekuensi hasil belajar biologi Peserta Didik dengan menggunakan Model Pembelajaran Kooperatif tipe Teams Games Tournament Berbantuan Audio Visual Terhadap Hasil Belajar Biologi Peserta Didik Kelas XI IPA Pada Materi Sistem Reproduksi Manusia. Dapat dilihat pada Tabel Post-Test diatas peserta didik yang mendapatkan interval nilai 85-100 dengan kategori sangat baik sebanyak 8 peserta dengan persentase sebesar 25\%, yang mendapatkan interval nilai 71-84 dengan kategori baik sebanyak 9 peserta dengan persentase sebesar 281\%, 66-70 dengan kategori cukup sebanyak 6 peserta didik dengan persentase sebesar 18,7\%, 0-65 dengan kategori kurang sebanyak 9 peserta didik dengan persentase sebesar $28,1 \%$. Adapun Statistik kategori hasil belajar dapat dilihat pada gambar 2 sebagai berikut:

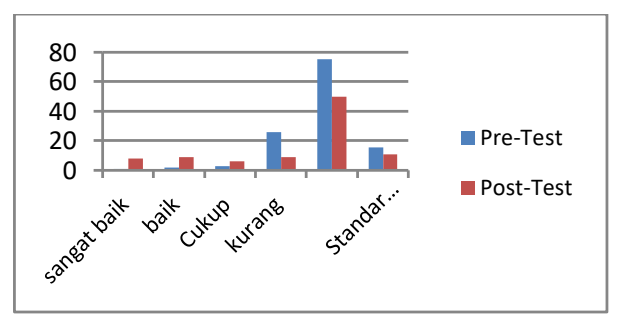

Gambar .2 Statistik Kategori Hasil Belajar Biologi Pre-Test dan Post-Test kelas XI IPA di SMA Negeri 20

Pangkep

c. Tingkat Ketuntasan Hasil Belajar Biologi Pre-Test kelas XI IPA di SMA Negeri 20 Pangkep

Tabel.5 Distribusi Tingkat Ketuntasan Hasil Belajar Biologi Pre-Test kelas XI IPA di SMA Negeri 20 Pangkep

\begin{tabular}{lllll}
\hline $\mathrm{N}$ & Interval & Kategoriket & $\begin{array}{l}\text { Freku } \\
\text { ensi }\end{array}$ & $\begin{array}{l}\text { Persent } \\
\text { ase }(\%)\end{array}$ \\
\hline 1 & nilai & untasan & 3 & $9,3 \%$ \\
2 & $0-74$ & Tidaktuntas & 29 & $90,6 \%$ \\
\hline & Jumlah & & 32 & $100 \%$
\end{tabular}

Sumber: Diolah dari data SPSS 25.

Berdasarkan Tabel 5 ketuntasan hasil belajar biologi sesuai aturan yang telah ditetapkan oleh SMA Negeri 20 Pangkep pada kelas XI IPA, peserta didik dikatakan tuntas pada mata pelajaran IPA biologi apabila nilai kriteria ketuntasan minimal (KKM) yaitu 75. Setelah peserta didik menggunakan Model Pembelajaran Kooperatif Tipe Teams Games Tournament Berbantuan Audio Visual Terhadap Hasil Belajar Biologi Peserta Didik Kelas XI IPA Pada Materi Sistem Reproduksi Manusia, Pada Pre-Testyang mendapat kategori tuntas sebanyak 3 peserta didik dengan persentase sebesar 9,3\% dan tidak tuntas sebanyak 29 
peserta didik dengan persentase $90,6 \%$ atau dibawah standar KKM pada tingkat ketuntasa hasil belajar biologi Pre-Test kelas XI IPA SMA Negeri 20 Pangkep.

Tabel.6 Distribusi Tingkat Ketuntasan Hasil belajar biologiPost-Test dkelas XI IPAdi SMA

Negeri 20 Pangkep

\begin{tabular}{|c|c|c|c|c|}
\hline $\begin{array}{l}\mathrm{N} \\
\mathrm{O}\end{array}$ & $\begin{array}{l}\text { Interval } \\
\text { nilai }\end{array}$ & $\begin{array}{l}\text { Kategorike } \\
\text { tuntasan }\end{array}$ & $\begin{array}{l}\text { Frek } \\
\text { uensi }\end{array}$ & $\begin{array}{l}\text { Persen } \\
\text { tase } \\
(\%)\end{array}$ \\
\hline 1 & $75-100$ & Tuntas & 17 & $53,1 \%$ \\
\hline 2 & $0-74$ & $\begin{array}{l}\text { Tidaktunta } \\
\mathrm{s}\end{array}$ & 15 & $46,8 \%$ \\
\hline & Jumlah & & 32 & $100 \%$ \\
\hline
\end{tabular}

Sumber: Diolah dari data SPSS 25.

Berdasarkan Tabel 6 Pada Post-

Test terdapat sebanyak 17 peserta didik yang tuntas dengan persentase sebesar $53.1 \%$ dan sebanyak 15 peserta didik tidak tuntas dengan persentase $46,8 \%$. Dapat dilihat pada gambar 3 sebagai berikut:

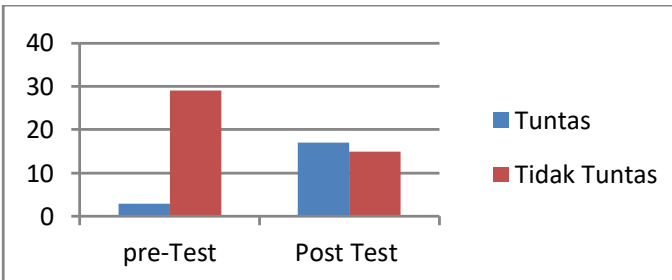

Gambar. 3 Statistik kategori ketuntasan Belajar Biologi Pre-test dan Post-test kelas XI IPA di SMA Negeri 20 Pangkep

2. Statistik Inferensial a. Uji Normalitas

Uji Normalitas digunakan untuk mengetahui apakah data yang diteliti berasal dari populasi yang berdistribusi normal atau tidak. Adapun dasar pengambilan keputusan untuk uji normalitas adalah sebagai berikut:

H0 : Sampel berasal dari populasi yang berdistribusi normal

H1 : Sample yang berasal dari populasi berdistribusi normal.

Tabel.7 Uji Normalitas Pre-Test dan

Post-Test

\begin{tabular}{|c|c|c|c|c|c|}
\hline \multicolumn{6}{|c|}{ Tests of Normality } \\
\hline & \multirow{2}{*}{\multicolumn{2}{|c|}{ Kelas }} & \multicolumn{3}{|c|}{ Shapiro-Wilk } \\
\hline & & & Statistic & Df & Sig. \\
\hline \multirow[t]{2}{*}{$\begin{array}{c}\text { Hasil } \\
\text { belajar }\end{array}$} & $\begin{array}{l}\text { Pre } \\
\text { eksperimen }\end{array}$ & & ,973 & 32 &, 586 \\
\hline & $\begin{array}{l}\text { Pos } \\
\text { eksperimen }\end{array}$ & test & ,954 & 32 & , 186 \\
\hline
\end{tabular}

Sumber : Diolah darti data SPSS Versi 25.

Berdasarkan Tabel 7 Test Of Normality Hasil belajar biologi yang telah diketahui, diperoleh nilai $p$ lebih dari $0,05(\mathrm{p}>\alpha=0,05)$ karena nilai $p$ (sig) pada kelas Pre-Test dan Post-Test eksperimen lebih besar dari $0,05(0,586$ $>\alpha=0,05)$ maka dapat disimpulkan bahwa Ho diterima yang berarti populasi dari data berdistribusi normal.

b. Uji Homogenitas

Dengan bantuan SPSS data yang diteliti bersifat homogen (Ho diterima) apabila 
nilai sig tabel tes homogenitas varian pada based of mean lebih dari tingkatan alpha $(\alpha)=0,05$. Untuk hasil pengujiuan selengkapnya dapat dilihat pada bagian lampiran Test of Homogeneity of Variance.

Tabel 4.7 Uji Homogenitas

\begin{tabular}{|c|c|c|c|c|c|}
\hline \multicolumn{6}{|c|}{ Test of Homogeneity of Variance } \\
\hline & & $\begin{array}{l}\text { Levene } \\
\text { Statistic }\end{array}$ & df1 & df2 & Sig. \\
\hline \multirow{4}{*}{$\begin{array}{l}\text { Hasil } \\
\text { belajar } \\
\text { siswa }\end{array}$} & $\begin{array}{l}\text { Based on } \\
\text { Mean }\end{array}$ & 3,032 & 1 & 62 & 087 \\
\hline & $\begin{array}{l}\text { Based on } \\
\text { Median }\end{array}$ & 2,042 & 1 & 62 & 158 \\
\hline & $\begin{array}{l}\text { Based on } \\
\text { Median } \\
\text { and with } \\
\text { adjusted } \\
\text { df }\end{array}$ & 2,042 & 1 & 51,025 & , 159 \\
\hline & $\begin{array}{l}\text { Based on } \\
\text { trimmed } \\
\text { mean }\end{array}$ & 3,001 & 1 & 62 & 088 \\
\hline
\end{tabular}

Sumber : Diolah dari SPSS 25.

Berdasarkan Tabel 4.7 Hasil belajar Peserta Didik pada uji homogenitas didapat hasil bahwa nilai $p$ Based on Mean pada kelas Pre-Test dan Post-Test eksperimen adalah 0,087 lebih dari tingkatan $(0,087>0,05)$ alpha $(\alpha)=$ 0,05 , yang berdasarkan pengambilan keputusan data variabel Pre-Testdan Post-Test eksperimen memiliki varian yang sama atau homogen.

c. Uji Hipotesis

Adapun hasil uji Hipotesis menggunakan uji-t sampel independen pada program SPSS dapat dilihat pada Tabel 4.8 sebagai berikut :

Tabel 4.8 Uji Hipotesis

\begin{tabular}{ccc|c|c}
\hline \multicolumn{4}{c}{ Paired Samples Test } \\
\hline & & \multicolumn{3}{c}{ Paired Differences } \\
\cline { 3 - 5 } & $\mathrm{t}$ & df & $\begin{array}{c}\text { Sig. } \\
(2- \\
\text { tailed })\end{array}$ \\
\hline $\begin{array}{c}\text { Pair } \\
1\end{array}$ & $\begin{array}{c}\text { Hasil belajar } \\
\text { siswa - Kelas }\end{array}$ & 29,396 & 63 &, 000 \\
\hline
\end{tabular}

Sumber : Diolah dari SPSS 25.

Berdasarkan Tabel 4.8 menunjukkan nilai $\mathrm{t}$ tabel sebesar 1,998341 dan $\mathrm{t}$ hitung sebesar 29,396 dimana $\mathrm{t}$ tabel $<\mathrm{t}$ hitung sehingga berdasarkan kriteria pengujian untuk uji hipotesis dinyatakan Ho ditolak sehingga $\mathrm{H} 1$ diterima yang berarti ada pengaruh penggunaan model pembelajaran kooperatif tipe Teams Games Tournament berbantuan audio visual terhadap hasil belajar peserta didik.

Penggunaan Model Pembelajaran Kooperatif Tipe Teams Games Tournament Berbantuan Audio Visual memberikan pengaruh yang positif terhadap hasil belajar Peserta Didik. Pengaruh tersebut dapat dilihat dari hasil rata-rata tes hasil belajar peserta didik melalui tes awal sebelum peserta didik diberi perlakuan ( Pre-Test) dan tes akhir setelah peserta didik diberi perlakuan (Post-Test), dimana nilai rata-rata pada peserta didik pada Pre-Test 53,43 kemudian nilai rata-rata meningkat menjadi 73,43 pada Post-Test.

Selain itu, hasil belajar biologi dapat dilihat melalui hasil analisis inferensial juga menunjukkan fakta yang sama. 
Berdasarkan kategori hasil belajar biologi sebelum diberi perlakuan pada nilai Pre-Test didominasi oleh kategori Kurang sebanyak 26 peserta didik dengan persentase sebesar $81.2 \%$ setelah diberi perlakuan pada nilai Post-Test didominasi oleh kategori Baik sebanyak 9 peserta didik dengan persentase sebesar $28,1 \%$.

Dengan itu, peserta didik akan mudah mengetahui materi tentang sistem reproduksi. Hal yang lebih positif adalah peserta didik menunjukkan hasil belajar yang baik. Hal ini terlihat ketika peserta didik aktif dalam proses pembelajaran dan mampu menjawab soalyang diberikan sesuai dengan langkahlangkah dalam Pembelajaran Kooperatif Tipe Teams Games Tournament Berbantuan Audio Visual.

\section{KESIMPULAN}

Dari hasil penelitian dan analisis data yang telah dilakukan dapat dikatakan bahwa ModelPembelajaran Kooperatif Tipe Teams Games Tournament Berbantuan Audio Visual Terhadap Hasil Belajar Biologi Peserta Didik Kelas XI IPA Pada Materi Sistem Reproduksi Manusia berpengaruh terhadap hasil belajar peserta didik di SMA Negeri 20 Pangkep

\section{UCAPAN TERIMA KASIH}

Ucapan terima kasih peneliti untuk kedua orang tua, keluarga Subrata, Gussay, seluruh dosen FKIP UMMA dan teman-teman Mahasiswa Program Studi Pendidikan Biologi FKIP UMMA, atas segala kerja samanya dan perjuangan yang sangat luar biasa selama peneliti menjalani perkuliahan

\section{DAFTAR PUSTAKA}

Anggraini, I. (2017). Pengaruh Model Pembelajaran Kooperatif Tipe Team Games Tournament Dan Media Audio Visual Pada Materi Sistem Pernapasan Manusia Terhadap Aktivitas Dan Hasil Belajar Siswa Mtsn Tungkob.Skripsi. (Online) Https://Doi.Org/10.1051/Mateccon f/201712107005 Diakses pada tanggal 09 November 2019.

Pramita Arif, W. (2018). Peningkatan Hasil Belajar Biologi Siswa Melalui Penerapan Model Pembelajaran Kooperatif Tipe Teams Games Tournament (Tgt).Jurnal Binomial, 1(1). (Online) Https://Doi.Org/10.1017/Cbo9781 107415324.004 Diakses pada tanggal 20 November 2019.

Rosdiani. (2014). Penerapan Model Pembelajaran Kooperatif Tipe Team Games Tournament (Tgt) Terhadap Peningkatan Hasil Belajar Siswa Kelas Xi-Ipa2 Pada Materi Sistem Pernapasan Di Sma Negeri 1 Sigli. Jurnal Biologi 
Edukasi Edisi 12, 6(1), 28-33. ( Online) Diakses pada tanggal 24 November 2019.

Rusman. $2016 . \quad$ Model-model pembelajaran mengembangkan profesalisme guru. Depok: PT Raja Grafindo Persada.

Septiawan, I. M. A. E., Rati, N. W., \& Murda, I. N. (2017). Pengaruh Model Pembelajaran Kooperatif Tipe Tgt Berbantuan Media Audio Visual Terhadap Hasil Belajar Ipa. E-Jurnal Pgsd Universitas Pendidikan Ganesha, 5(2). (Online) Https://Doi.Org/10.23887/Jppp.V2 i3.16285 Diakses pada tanggal 24 November 2019.

Shoimin, Aris. 2016. 68 Model pembelajaran inovatif dalam kurikulum 2013. Yogyakarta: Ar-Ruzz Media.

Yuni, R. 2016. Pengaruh penerapan model pembelajaran kooperatif tipe kancing gemerincing dan disiplin belajar terhadap hasil belajar ekonomi siswa kelas $\mathrm{x}$ di sma negeri 3 kota solok. Jurnal Of Educational Studies, Volume 1, Nomor 2, hal. 178-188. 